\title{
Circulation of avian paramyxoviruses in wild birds of Kazakhstan in 2002-2013
}

\author{
Kobey Karamendin ${ }^{1 *}$ D, Aidyn Kydyrmanov ${ }^{1}$, Aigerim Seidalina ${ }^{1,5}$, Saule Asanova', Klara Daulbayeva', \\ Yermukhammet Kasymbekov ${ }^{1,5}$, Elizaveta Khan ${ }^{1,5}$, Sasan Fereidouni ${ }^{2,3,4}$, Elke Starick ${ }^{2}$, Kainar Zhumatov ${ }^{1}$ \\ and Marat Sayatov ${ }^{1}$
}

\begin{abstract}
Background: Screening wild birds for avian paramyxoviruses is of increasing importance. 6913 samples of tracheal and cloacal swabs were collected during 2002-2013 and tested to study the prevalence of APMVs in wild avifauna of Kazakhstan. As a result, 45 isolates were obtained during this period and their ecological niches and genetic relationships were defined.

Methods: Tracheal and cloacal samples from wild birds were collected using sterile swabs placed in viral transport medium and kept in liquid nitrogen until delivery to the laboratory. Samples were inoculated into 10-day-old embryonated chicken eggs and reverse transcription PCR (RT-PCR) assays were performed via a one-step protocol. The PCR products were sequenced and phylogenetic trees were constructed using the 'Neighbour Joining' method.

Results: Six thousand nine hundred thirteen samples from 183 bird species were investigated and 45 isolates belonging to four different serotypes APMV-1, APMV-4, APMV-6 and APMV-8 were identified. All APMVs were isolated predominantly from birds belonging to Anatidae family (ducks and geese) and only one APMV-4 isolate was obtained from shorebird (Curlew) on the Caspian seashore. Genetic studies showed that the recovered APMV-1 strains had highest homology with European isolates. APMV-4 strains isolated in 2003, and APMV-6 and APMV-8 isolated in 2013 were $99 \%$ identical to isolates from Far East.

Conclusion: This is the first reported characterization of avian paramyxoviruses from wild birds isolated in Kazakhstan. These data confirm the wide distribution of APMV-1, APMV-4 and APMV-6 in the Asian subcontinent. The obtained data contribute to the accumulation of knowledge on the genetic diversity and prevalence of APMVs in wild bird populations.
\end{abstract}

Keywords: Avian paramyxovirus, Kazakhstan, Wild bird, Sequencing, Monitoring, Phylogenetics

\section{Background}

Paramyxoviruses (PMV) are negative-strand RNA viruses circulating among mammals, birds and reptiles. Their viral RNA encodes six major proteins: nucleocapsid protein (NP); phosphoprotein (P); matrix protein (M); fusion protein (F); haemagglutinin-neuraminidase (HN) and large RNA polymerase (L) as well as two nonstructural proteins V and W [1]. The APMV-6 serotype has a unique additional protein $\mathrm{SH}$ which is not found in the other serotypes. Its biological function in APMVs is not known, but it is hypothesized to play an important

\footnotetext{
*Correspondence: kobey@nursat.kz

${ }^{1}$ Institute of Microbiology and Virology, 103 Bogenbay batyr Str, Almaty 050010, Kazakhstan

Full list of author information is available at the end of the article
}

role in blocking the TNF- $\alpha$-mediated apoptosis pathway in other Paramyxoviridae representatives including SV5 and Mumps virus [2].

Avian paramyxoviruses (APMV) belong to the genus Avulavirus of Paramyxoviridae family and to date has been found to cause diseases with varying clinical manifestations in more than 200 wild and domestic bird species. They are divided into twelve serotypes based on a haemagglutination inhibition assay (APMV-1 -12) [3].

The most dangerous for poultry is APMV-1 (Newcastle disease virus), which is widespread in poultry around the world and inflicts significant economic damage. The disease ranges from asymptomatic infection to severe epizootics, often resulting in complete loss of commercial flocks. 
Little is known about the molecular and biological characteristics and pathogenicity of other APMV serotypes. In poultry they primarily cause respiratory infection or intestinal disease with varying degree of pathogenicity accompanied by a decrease in egg production, weight gain, conjunctivitis and pneumonia with variable mortality rates [4]. APMV-4 and 8 have been isolated from ducks and other wild birds with no clinical signs of disease $[5,6]$. APMV-6 virus causes mild respiratory disease and is associated with a drop in egg production in turkeys [7]. Experimental infection of chickens with APMV-4 and APMV-6 showed mild interstitial pneumonia, catarrhal tracheitis, and BALT or GALT hyperplasia, suggestive of viral disease [8]. APMV-8 is a rare serotype that was first isolated in 1976 from a feral Canadian goose in the United States of America. APMV-10-12 have been isolated exclusively from wild birds with no evidence of any disease.

In Kazakhstan APMV-1 was first isolated in 1982 from synanthropic birds (house and tree sparrow, grey crow, magpie). In February 2005 it was isolated from wild pigeons during a mass-mortality [9, 10]. Other serotypes of APMV have not previously been isolated and described in Kazakhstan before this research aside from APMV-2 strains from domestic poultry in 1987-1989 [11].

Kazakhstan has a vast territory crossed by intercontinental flyways, and hundreds of bird species concentrate in wetlands during migration and breeding periods
(Fig. 1). Here we present the results of the first largescale ecological study of APMV circulation among wild birds in the Central Asian region, isolation of the contemporary virus variants and definition of their ecological niches and genetic relationships.

\section{Results}

\section{Virus detection and identification}

Large scale monitoring of wild birds, focused mainly on AIV and APMV, was conducted in 2002-2013 and resulted in 6913 samples collected from 17 avian orders, 38 families and 183 species. Taxa from a range of niches were sampled, including aquatic (84\%), and terrestrial (16\%) avifauna. (Additional file 1: Table S1).

Sampling sites covered almost all migrating birds' nesting and resting sites: Tengiz-Korgalzhyn Lakes System Central and Northern Kazakhstan, Caspian seashore Western Kazakhstan, Balkhash-Alakol lakes system in South-Eastern Kazakhstan, and Chokpak ornithological station in Southern Kazakhstan (Fig. 2).

Overall, 45 APMV strains were isolated following culture in embryonated chicken eggs. After sequencing of PCR products and subsequent BLAST analysis it was determined that 23 isolates belonged to APMV-1, thirteen isolates to APMV-4, one isolate to APMV-6 and eight isolates to APMV-8 (Table 1). Out of 6913 samples, 45 were positive and the isolation rate was $0.65 \%$.

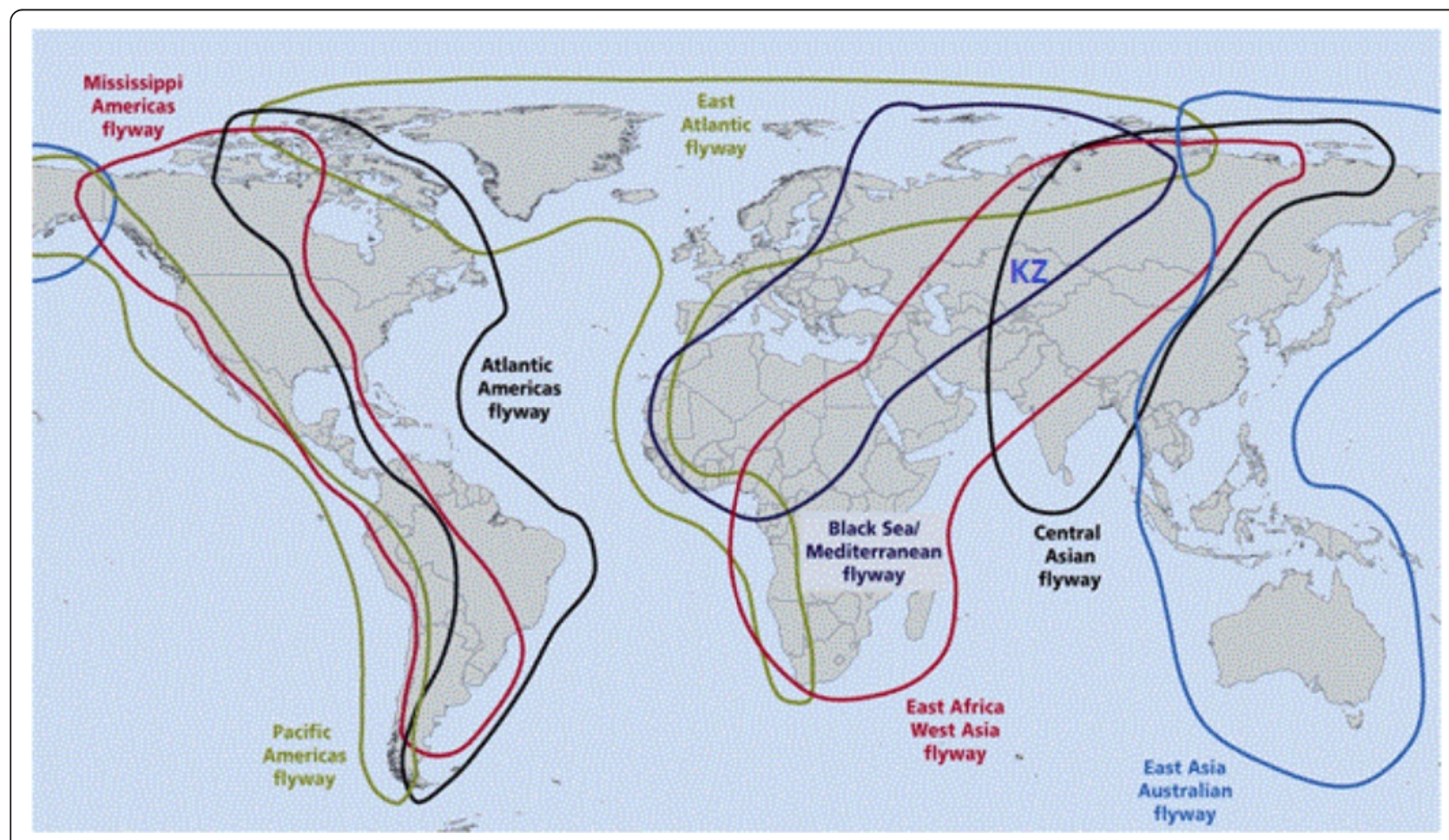

Fig. 1 Major Flyways crossing Kazakhstan (KZ) @ www.eaaflyway.net/about/the-flyway/ 


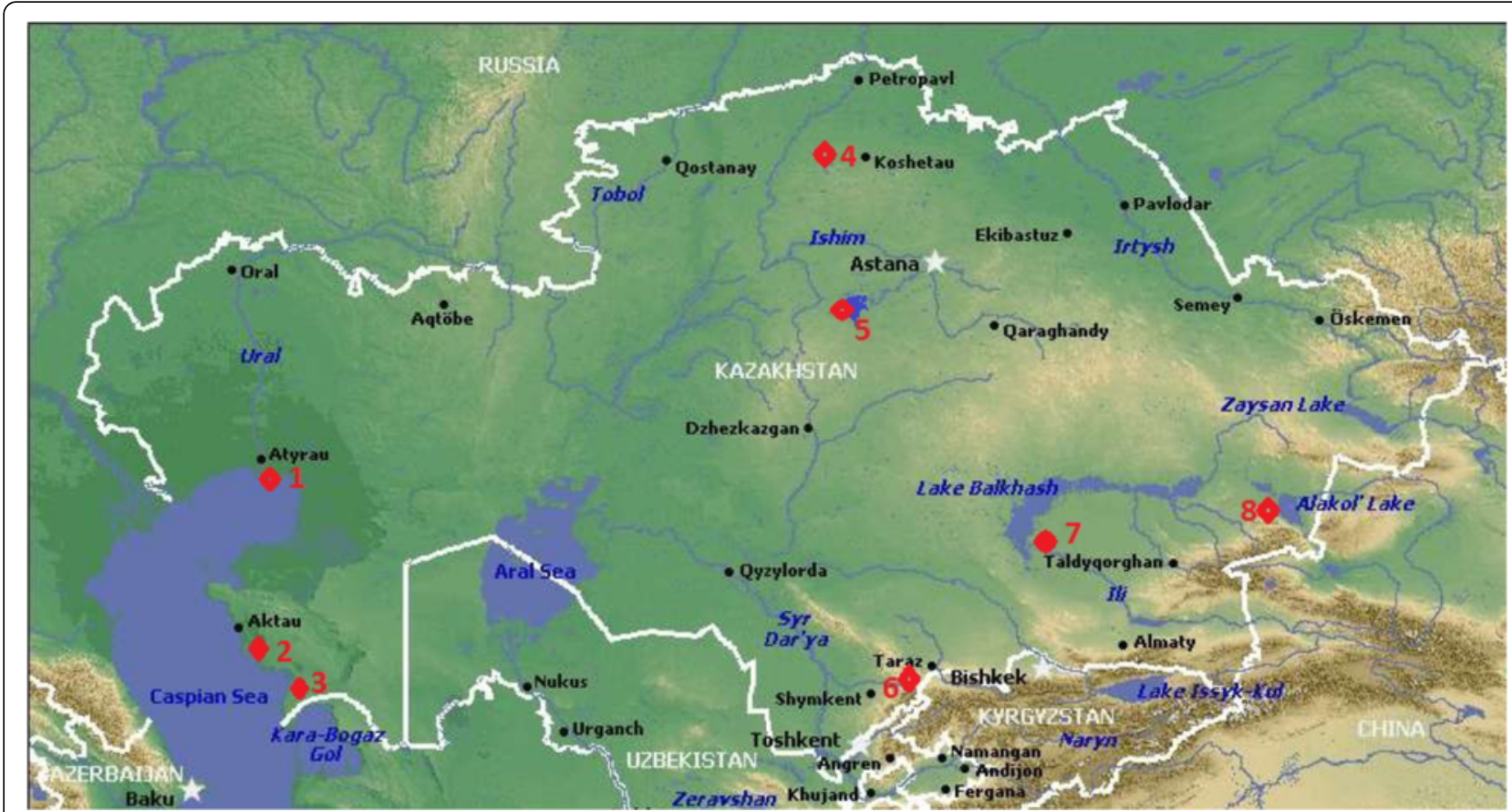

Fig. 2 Places of sampling in Kazakhstan. @ www.kazakhstandiscovery.com/kazakhstan-map.html. Sampling locations in Kazakhstan are marked with red rhombs. Numeration of sampling sites are the following: 1-Northern Caspian, 2 and 3 - Middle Caspian (Western Kazakhstan); 4 - Northern Kazakhstan; 5 - Central Kazakhstan; 6 - Southern Kazakhstan; 7 - Balkhash Lake, 8 - Alakol Lake (Southeastern Kazakhstan)

Table 1 Avian species samples positive for APMVs in Kazakhstan, 2002-2013

\begin{tabular}{|c|c|c|c|c|c|c|c|}
\hline \multirow[t]{2}{*}{ Order } & \multirow[t]{2}{*}{ Family } & \multirow[t]{2}{*}{ Species } & \multirow{2}{*}{$\begin{array}{l}\text { No of } \\
\text { samples }\end{array}$} & \multicolumn{4}{|c|}{ No of positive } \\
\hline & & & & APMV-1 & APMV-4 & APMV-6 & APMV-8 \\
\hline \multirow[t]{14}{*}{ Anseriformes } & Anatidae & Whooper Swan & 7 & & & & 1 \\
\hline & & Greylag Goose & 175 & 5 & & & \\
\hline & & White-fronted Goose & 173 & 2 & & & 4 \\
\hline & & Bean & 7 & & & & 2 \\
\hline & & Lesser white-fronted Goose & 27 & & & & \\
\hline & & Ruddy Shelduck & 334 & 4 & & & \\
\hline & & Mallard & 291 & 3 & 1 & & \\
\hline & & Gadwall & 145 & & 5 & & \\
\hline & & Wigeon & 45 & 4 & & & \\
\hline & & Pintail & 103 & 1 & & & \\
\hline & & Shoveler & 41 & & 3 & & \\
\hline & & Teal & 191 & 2 & 3 & & \\
\hline & & Common pochard & 88 & 1 & & & \\
\hline & & Red-crested Pochard & 234 & 1 & & 1 & \\
\hline \multirow[t]{2}{*}{ Charadriiformes } & Scolopacidae & Curlew & 5 & & 1 & & \\
\hline & & Little stint & 169 & & & & 1 \\
\hline Total & & & & 23 & 13 & 1 & 8 \\
\hline
\end{tabular}


APMV-1 was isolated for the first time in Central Kazakhstan in 2005 in graylag geese and later in the same region in 2006 and 2009. In 2008 and 2013 other viruses of this serotype were isolated from ducks in Southern Kazakhstan. All viruses were identified in birds belonging to Anatidae family (ducks and geese), 7 isolates from geese and 16 from ducks of various species.

APMV-4 was isolated in 2003 near the Alakol lake close to the Chinese border. The second isolation of this serotype was made in the Northern Caspian in 2009. Viruses of this serotype were also isolated predominantly from Anatidae family but only one was obtained from a shorebird (Curlew) on Caspian seashore. APMV-6 was isolated once from a duck in Alakol Lake in Southeastern Kazakhstan in 2013. APMV-8 was isolated twice in 2013 in samples from two separate geographically distant regions of Northern Caspian and Southern Siberia (Table 2).

The prevalence of APMV positive infection varies each year between $0.15 \%$ in 2005 and $2.73 \%$ in 2006. The mean prevalence over a 12 year period was $0.65 \%$.

The most prevalent serotypes were APMV-1 (0.33\% all years and $2.73 \%$ in 2006), APMV-4 (0.18\% and $0.86 \%$ in 2009), APMV-8 (0.11\% and 1.64 in 2013) and APMV-6 (0.01\% and $0.63 \%$ in 2003), respectively.

Among various sampling locations, the APMVs were detected most frequently in Central Kazakhstan (44\%, all APMV-1), Western Kazakhstan (26\%, all APMV-4), Northern Kazakhstan (15\%, all APMV-8), Southern Kazakhstan ( 9 \%, APMV-1 and APMV-8) and Southeastern Kazakhstan (5 \%, APMV-4 and APMV-6), respectively.

\section{Genetic characterization}

Representatives of each APMV serotype strain from all various times and regions were selected for sequencing. The F genes of APMV-1, 4 and the complete genomes of APMV-6 and 8 were sequenced.

BLAST search of the novel APMV-1 strains showed the highest homology (99 \%) with a European isolate
APMV-1/Pochard/Finland/13193/06. APMV-4 strains isolated in 2009 were 99 \% homologous to European isolate APMV4/Teal/Djankoy/9-17-11/10 and one APMV-4 strain isolated in 2003 was 99 \% identical to Korean isolate APMV-4/KR/YJ/2006.

APMV-6 isolate showed the highest (99 \%) homology with a Chinese isolate mallard/Jilin/190/2011 and APMV8 isolates were $99 \%$ homologous to Japanese strain pintail/Wakuya/20/78.

Analysis of the deduced amino acid motifs for the fusion protein cleavage site of isolated APMVs showed that all of them are of an avirulent type containing one or two basic amino acids (Table 3). Velogenic APMV-1 strains contain a multibasic cleavage site having consensus sequence of RRQKRQF with a polybasic furin motif $\mathrm{RX}[\mathrm{R} / \mathrm{K}] \mathrm{RQ}$ that is cleaved by intracellular furin or furinlike protease. Lentogenic APMV-1 strains lack this polybasic site and need extracellular trypsin like protease found in the epithelium of the respiratory and intestinal tracts [12].

During evaluation of in vitro replication of APMVs it was determined that of APMV 2-9 serotypes only APMV-2, -3 and -5 replicate efficiently in cell culture, but only two latter serotypes induced syncytium formation in infected cells [4]. The other APMVs (serotypes 4, $6,7,8$, and 9) have one or two basic amino acids in their cleavage site sequences and exhibited single cell infection and inefficient replication in vitro.

Phylogenetic analysis of the F- gene of Kazakhstan APMV-1 strains was conducted to define their relationships with other viruses from GenBank. Kazakhstan APMV-1 strains from wild birds have $99 \%$ similarity with Finnish isolate and so they formed a monophyletic group inside the class 1 , consisting of non-pathogenic viruses.

The phylogram (Fig. 3a), suggests that the velogenic NDV strain APMV-1/chicken/Almaty/41/2013 (Genotype VII) that caused a NDV outbreak in poultry in Almaty region in 2013, is not closely related to the wild APMV-1 isolates presented here. Combined phylogenetic analysis of the other serotype viruses (Fig. 3b), showed that APMV-6 isolates formed a monophyletic group with Jilin/

Table 2 Spatial and temporal characterization of APMV-positive samples collected in Kazakhstan in 2002-2013

\begin{tabular}{|c|c|c|c|c|c|c|c|c|}
\hline \multirow[t]{2}{*}{ Serotype } & \multirow{2}{*}{$\begin{array}{l}\text { No of } \\
\text { isolates }\end{array}$} & \multirow[t]{2}{*}{ Region } & \multicolumn{6}{|c|}{ Year/ Collected Samples } \\
\hline & & & $2003 / 158$ & $2005 / 662$ & $2006 / 586$ & $2008 / 1088$ & $2009 / 1392$ & $2013 / 486$ \\
\hline \multirow[t]{2}{*}{ APMV-1 } & 23 & Central Kazakhstan & & 1 & 16 & & 3 & \\
\hline & & Southern Kazakhstan & & & & 2 & & 1 \\
\hline \multirow[t]{2}{*}{ APMV-4 } & 13 & South-eastern Kazakhstan & 1 & & & & & \\
\hline & & Western Kazakhstan & & & & & 12 & \\
\hline APMV-6 & 1 & South-eastern Kazakhstan & & & & & & 1 \\
\hline \multirow[t]{2}{*}{ APMV-8 } & 8 & Northern Kazakhstan & & & & & & 7 \\
\hline & & Southern Kazakhstan & & & & & & 1 \\
\hline Total & & & 1 & 1 & 16 & 2 & 15 & 10 \\
\hline
\end{tabular}


Table 3 Analysis of the deduced amino acid motifs for the fusion protein cleavage site

\begin{tabular}{ll}
\hline APMV-1 & \\
APMV-1/greylag goose/Astana/1375/2005 & SGGERQERLVG \\
APMV-1/pintail/Korgalzhyn/1786/2006 & SGGERQERLVG \\
APMV-1/wigeon/Korgalzhyn/1819/2006 & SGGERQERLVG \\
APMV-1/red crested pochard/Korgalzhyn/3645/2009 & SGGERQERLVG \\
APMV-1/slender-billed gull/Korgalzhyn/3651/2009 & SGGERQERLVG \\
APMV-1/ shelduck/Chokpak/5717/2013 & SGGERQERLVG \\
APMV-1/chicken/Almaty/41/2013 & SGGRRQKRFIG \\
APMV-4 & \\
APMV-4/Gadwall/Aktau/3825/09 & RDADIQPRFIG \\
APMV-4/Shoveler/Aktau/3819/09 & RDADIQPRFIG \\
APMV-4/Curlew/Aktau/3818/09 & RDADIQPRFIG \\
APMV-4/Teal/Aktau/3820/09 & RDADIQPRFIG \\
APMV-4/gadwall/Alakol/386/04 & \\
APMV -6 & QNPAPEPRLIG \\
APMV-6/red-crested_pochard/Bakanas/5842/2013 & \\
APMV-8 & SETYPPQTRLIG \\
APMV-8/Little Stint/Chokpak/5669/2013 & \\
APMV-8/white-fronted goose/Northern Kazakhstan/ & SETYPQTRLIG \\
5747/2013 & \\
APMV-8/ white-fronted goose/Northern Kazakhstan/ & S749/2013 \\
APMV-8/ Bean Goose/Northern Kazakhstan/5764/2013 & SETIG \\
APMV-8/white-fronted goose/Northern Kazakhstan/ & S765/2013 \\
\end{tabular}

2011 isolate from China. APMV-8 formed a separate branch from other viruses known to date (Delaware/76 and Wakuya/78).

\section{Discussion}

Central Asia is a very important region where flyways connecting the Far East, Europe, Siberia and Southern Asia cross each other. Particularly important is the Caspian seashore, where cases of reassortment among avian influenza viruses of American and Eurasian lineages have been detected [13].

Kazakhstan has a vast territory where three large flyways of water birds cross: Black Sea-Mediterranean, West Asian-East African and Central Asian. Numerous places of nesting, moulting and summer concentration of birds play an important role in the maintenance of the populations of more than 150 water bird species inhabiting Central Asia.

There is a limited research on circulation of APMVs among wild birds in Kazakhstan and globally. It is known that wild birds serve as the main natural reservoir for APMV serotypes. Among them APMV-1 is the most widespread [14] followed by APMV-4 and 6 [15].
Other serotypes, APMV-2 [16, 17], APMV-3 [18, 19], APMV-7 [16] and APMV-9 [20] appear to be comparatively rare in wild avifauna. Recently, novel strains, APMV-10-12 have been isolated exclusively from wild birds [2, 13, 21, 22]. APMV-1, 4, 6 and 8 have previously been isolated and reported from other countries in Asia [23-26], and we also detected all the above serotypes in wild avifauna of Kazakhstan in this study.

APMV-1 is a globally spread pathogen [1] and its isolation in Kazakhstan during 2003-2013 confirms this assertion. The main potential threat of this serotype is that low pathogenic strains can become highly pathogenic after several passages through poultry [27]. It was revealed that APMV-1 isolated in this study from wild birds are of another origin from strains caused lethal outbreaks in poultry in 2013 in Southeastern Kazakhstan (unpublished). All APMV-1 isolates in this research were isolated from ducks and geese considered to be main carriers of this serotype in Eurasia. In contrast, in the Americas APMV-1 viruses were isolated from shorebirds and gulls $[28,29]$.

APMV-4 is widely spread in Asia and globally [30-32]. Comparative phylogenetic analysis of the F-gene of the isolate APMV-4/gadwall/Alakol/386/04 showed the greatest similarity to Korean isolate APMV-4/KR/YJ/06 and Chinese isolate APMV4/duck/China/G302/2012. We propose that viruses of this cluster circulate independently in Asia. APMV-4 isolates from 2009 were almost identical to Ukrainian isolate APMV4/Teal/ Djankoy/9-17-11/10, suggesting dissemination via flyways shared with European birds. It is suggested that Korean APMV-4 from the Far East and European isolates from Belgium viruses evolved separately from the reference strain APMV-4/duck/HK/D3/75 [24]. All known APMV-4 strains were isolated from ducks and geese, except one Kazakhstan strain obtained from a shorebird.

Genetic studies of the F-gene of APMV-6 has shown divergence into two separate clusters: the first consists of viruses (including a Kazakh strain), ascending to reference strain APMV-6/duck/Hong Kong/18/199/1977; the second is represented by viruses with a deletion of four nucleotides in their genomes, APMV-6/red-necked stint/Japan/8KS0813/2008 and APMV-6/duck/Italy/ IT4524-2/2007 [33].

The new Kazakh virus was shown to be close to APMV-6/mallard/Jilin/127/2011 (98.8 \%), which can be explained by the common border between Kazakhstan and China, where wild ducks flyways cross.

As of today APMV-8 strains have been isolated only twice - in the USA and Japan in the 1970s. [34, 35]. A APMV-8 serotype was isolated again in Japan in 2007 from a tundra swan [23]. Thus isolation of this serotype in two regions remote from each other in Kazakhstan is 

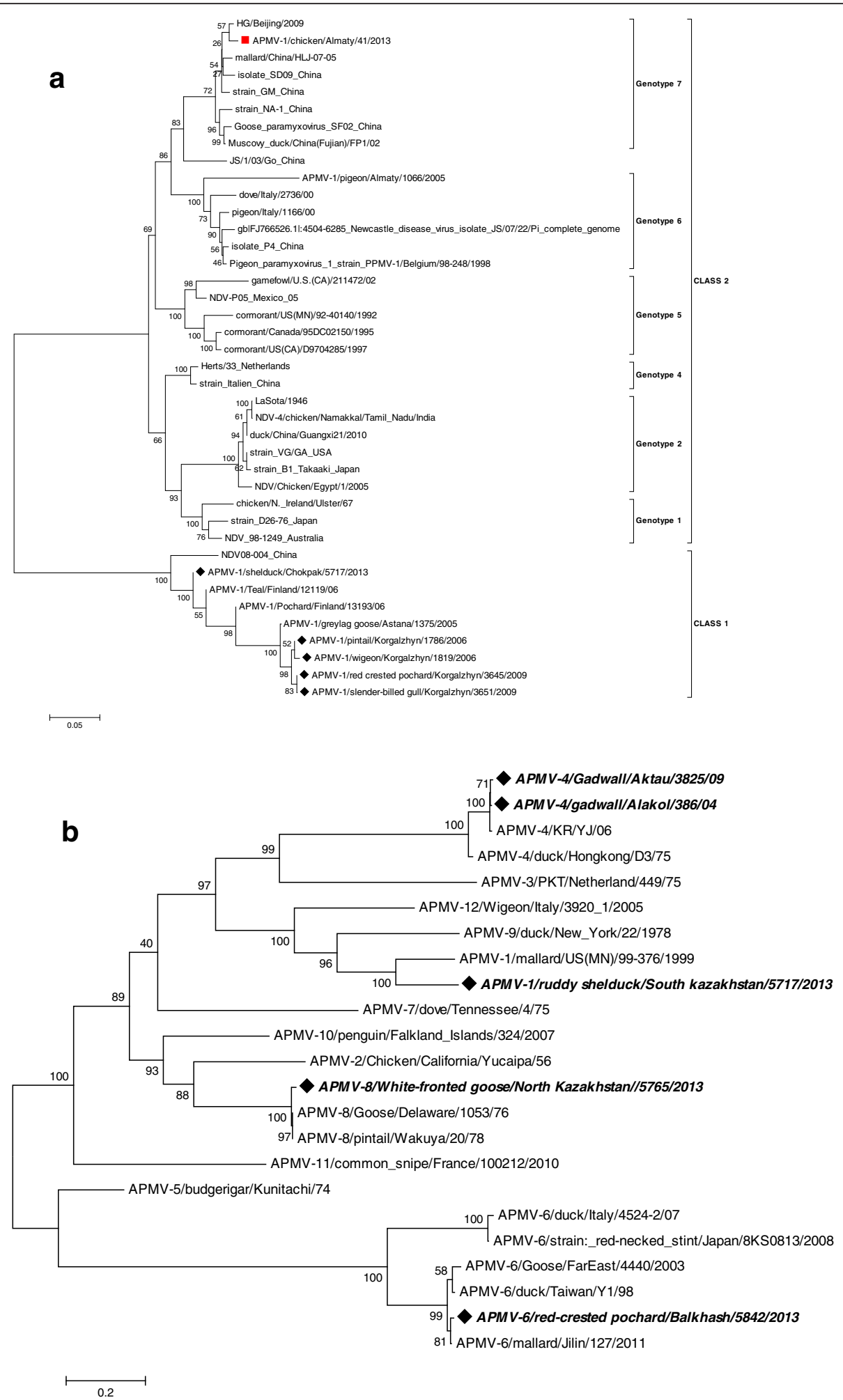

Fig. 3 Phylogenetic analyses of the APMV-1 (a) and other serotypes (b) from Kazakhstan. Isolates from the Kazakhstan wild birds are marked with black diamonds, velogenic APMV-1 strain is marked with red square 
a very rare case, which substantially increases our knowledge about its distribution and evolution.

The reported large scale monitoring resulted in isolation of 45 APMV strains belonging to four serotypes APMV-1, 4, 6 and 8 will enhance the understanding the paramyxoviruses circulation in wild birds of Central Asia and the world.

This study confirms the primary role of wild bird populations as a reservoir of APMV-4, 6 and 8 in nature and potential source of genetic material for the emergence of epizootic APMV-1 variants.

\section{Methods}

\section{Samples collection}

Samples from wild birds were collected in three ways: cloacal and tracheal swabs were obtained from birds captured by ornithologists for banding during studies of migratory patterns, sampling during seasonal hunting for wild birds and samples from freshly dropped faeces of wild aquatic birds.

Samples from terrestrial birds were mostly collected in Chokpak ornithological station in Southern Kazakhstan during banding. Samples from aquatic birds were collected in spring and autumn during mass concentrations, and samples from terrestrial birds throughout the year.

Tracheal and cloacal samples from birds were taken using sterile swabs placed in viral transport medium containing $2000 \mathrm{U} / \mathrm{ml}$ penicillin, $2 \mathrm{mg} / \mathrm{ml}$ streptomycin, $50 \mu \mathrm{g} / \mathrm{ml}$ gentamycin, $50 \mathrm{U} / \mathrm{ml}$ nystatin and $0.5 \%$ bovine serum albumin. During the fieldwork, samples were kept in liquid nitrogen, and were stored at $-70{ }^{\circ} \mathrm{C}$ after return to the laboratory.

\section{Virus isolation}

Samples were firstly screened by RT-PCR targeting the $M$ gene of avian influenza viruses (AIV). Then negative for AIV samples were inoculated into 10-days-old embryonated chicken eggs (ECE) and incubated 48 hours at $+36^{\circ} \mathrm{C}$ [36]. The presence of the virus in allantoic fluid was detected using hemagglutination assay with chicken red blood cells.

\section{RNA extraction and RT-PCR}

Viral RNA was extracted from $140 \mu \mathrm{l}$ of hemagglutination assay positive allantoic fluid using the QIAamp RNA Mini kit (Qiagen, Hilden, Germany) in accordance with the manufacturer's recommendations.

Reverse transcription PCR (RT-PCR) assays were performed on the basis of one-step protocol using appropriate RT-PCR kit (AccessQuick One-Step RT-PCR Kit, Promega) according to the manufacturer's instructions. Pan-PMV primers targeting the conservative fragment of L-gene were used [37]. The cycling conditions consisted of $45 \mathrm{~min}$ at $48^{\circ} \mathrm{C}$ (reverse transcription) and then an initial denaturation at $94^{\circ} \mathrm{C}$ for $2 \mathrm{~min}$ followed by 35 cycles of $94^{\circ} \mathrm{C}$ for $15 \mathrm{~s}, 50{ }^{\circ} \mathrm{C}$ for $30 \mathrm{~s}$, and $72^{\circ}$ $\mathrm{C}$ for $30 \mathrm{~s}$ and a final extension at $72^{\circ} \mathrm{C}$ for $10 \mathrm{~min}$. The final PCR products were visualized on $2 \%$ agarose gel.

The pan-PMV primers did not amplify the APMV-4 subtype and therefore we used our own degenerate primer pair targeting $1481 \mathrm{bp}$ fragment of the F-gene: APMV-4 Fgene-Fw - CAAAGTCYGARGGGATTAGGG and APMV-4 Fgene Rv - CACCGAGAACAAYAATMAGACC.

\section{Sequencing and molecular characterization}

After purification, the PCR products were sequenced using the same PCR primers on an ABI 3730xl DNA analyser (Applied Biosystems, USA) using BigDye Terminator Kit v.3.1 Sequencing Kit (Applied Biosystems).

For complete genome sequencing, viral RNA was used as a template for double-stranded cDNA synthesis (Roche). A Covaris M220 ultrasonicator was used for DNA fragmentation. For library preparation, Illumina adaptors (Bioo Scientific) and SPRIworks fragment library cartridge II (Beckman Coulter) were used, with manual size selection afterward. The quality of the library was checked on a Bioanalyzer 2100 (Agilent Technologies). Quantity was determined via quantitative PCR (qPCR) with the Kapa library quantification kit (Kapa Biosystems). Paired-end sequencing was performed on an Illumina MiSeq instrument using the MiSeq reagent kit version 3. Raw sequence data were analyzed and assembled using the Genome Sequencer software suite (version 2.8; Roche).

Obtained nucleotide sequences were aligned using Mega 5.0 [38] software and were deposited in the GenBank data base under accession numbers [Genbank:KP762799, KU366512-KU366520]. Fifty one other full-length and partial sequences from public databases were used for this analysis. Phylogenetic trees were constructed by comparing sequences of the isolated APMVs with respective nucleotide sequences from GenBank using the 'Neighbour Joining' method and the TamuraNei model in MEGA 5.0 software [39], with 1000 bootstrap replications to assign confidence levels to branches.

\section{Conclusions}

6913 samples from 183 wild bird species were collected during 2002-2013 and tested to study the prevalence of APMVs in avifauna of Kazakhstan. As a result, 45 strains belonging to four APMV serotypes were isolated during this period The obtained data confirm the wide distribution of APMV-1, APMV-4 and APMV-6 in the Asian subcontinent and contribute to the accumulation of 
knowledge on the genetic diversity and prevalence of APMVs in wild bird populations.

\section{Additional file}

Additional file 1: Table S1. Avian species tested for APMVs in

Kazakhstan, 2002-2013. (DOCX 48 kb)

\section{Abbreviations}

APMV: avian paramyxoviruses; RNA: ribonucleic acid; AIV: avian influenza virus; RT-PCR: reverse transcription polymerase chain reaction.

\section{Competing interests}

The authors declare that they have no competing interests.

\section{Authors' contributions}

The manuscript was written and drafted by KK. Conception of the idea and proof reading were conducted by MS, KZ and AK. Samples collection and virus isolation were conducted by SA, KD, EK, YK. RT-PCR, sequencing and data analyses were conducted by SF, ES, AS, KK. All authors read and approved the final manuscript.

\section{Acknowledgements}

We thank the colleagues from National Center of Biotechnology for sequencing APMV genes and the laboratory for NGS and microarray diagnostics of Friedrich-Loeffler-Institite, Insel-Riems, Germany. This work was supported by grants from the Ministry of Education and Science of the Republic of Kazakhstan: "Novel serotypes of avian paramyxoviruses: isolation, molecular-genetic characterization and development of tools for their diagnosis" (0115PK01086) and "Study of ecology and genetic diversity of paramyxoviruses in wild and domestic birds in Kazakhstan" (0112PK02470). We are thankful to Dr. Simon Goodman (University of Leeds, UK) for critical viewing and English proof-reading this article.

\section{Author details}

${ }^{1}$ Institute of Microbiology and Virology, 103 Bogenbay batyr Str, Almaty 050010, Kazakhstan. ${ }^{2}$ Friedrich Loeffler Institute, Greifswald, Insel Riems, Germany. ${ }^{3}$ WESCA Wildlife Network, Greifswald, Germany. ${ }^{4}$ Present Address: University of Veterinary Medicine Vienna, Research Institute of Wildlife Ecology, Vienna, Austria. ${ }^{5}$ Kazakh National Agrarian University, 8 Abay Str. 050010, Almaty, Kazakhstan.

\section{Received: 30 September 2015 Accepted: 25 January 2016}

\section{Published online: 04 February 2016}

\section{References}

1. Alexander DJ. Newcastle disease virus and other avian paramyxoviruses. In: A laboratory manual for the isolation and identification of avian pathogens. Kennett Square, PA: The American Association of Avian Pathologists; 1998.

2. Wilson RL, Fuentes SM, Wang P, Taddeo EC, Klatt A, Henderson AJ, et al. Function of small hydrophobic proteins of paramyxovirus. J Virol. 2006:80:1700-9.

3. Terregino C, Aldous EW, Heidari A, Fuller CM, De Nardi R, Manvell RJ, et al. Antigenic and genetic analyses of isolate APMV/wigeon/ttaly/3920-1/2005 indicate that it represents a new avian paramyxovirus (APMV-12). Arch Virol. 2013;158(11):2233-43.

4. Kim S-H, Xiao S, Shive H, Collins PL, Samal SK. Replication, Neurotropism, and Pathogenicity of Avian Paramyxovirus Serotypes 1-9 in Chickens and Ducks. PLoS One. 2012;7(4), e34927.

5. Gough RE, Alexander DJ. Avian paramyxovirus type 4 isolated from a ringed teal (Calonetta leucophrys). Vet Rec. 1984;115:653.

6. Alexander DJ, Hinshaw VS, Collins MS, Yamane N. Characterization of viruses which represent further distinct serotypes (PMV-8 and PMV-9) of avian paramyxoviruses. Arch Virol. 1983:78:29-36.

7. Alexander DJ. Newcastle disease and other avian Paramyxoviridae infections. In: Calnek BW, editor. Diseases of Poultry. Ames: lowa State University Press; 1997. p. 541-69.
8. Warke A, Stallknecht D, Williams SM, Pritchard N, Mundt E. Comparative study on the pathogenicity and immunogenicity of wild bird isolates of avian paramyxovirus 2, 4, and 6 in chickens. Avian Pathol. 2008;37:429-34.

9. Beisembaeva RU, Sayatov MK, Daulbaeva KD, Khrokov W, Dubova EA. Virological and serological survey of wild avifauna in Almaty and suburbs. Ecol Virus. 1982;147-151.

10. Bogoyavlensky AP, Berezin VE, Prilipov AG, Usachev E, Lyapina O, Korotetskiy IS, et al. Newcastle disease outbreks in Kazakhstan and Kyrgyzstan during 1998, 2000, 2001, 2003, 2004 end 2005 were caused by viruses of the genotypes VII b and VII d. Virus Genes. 2009;39:94-101.

11. Saiatov MK, Ter-Pogosian VE, Daulbaeva KD, Dmitriev GA, lamnikova SS, Zhumatov KK, et al. Yucaipa-like viruses isolated in Kazakhstan in 1987-1989. Vopr Virusol. 1992:37(2):116-8. Article in Russian.

12. Samal SK. Newcastle disease and related avian paramyxoviruses. In: The biology of paramyxoviruses. Norfolk, U.K: Caister Academic Press; 2011. p. 69-114.

13. Karamendin K, Kydyrmanov A, Zhumatov K, Asanova S, Ishmukhametova N, Sayatov M. Phylogenetic analysis of avian influenza viruses of H11 subtype isolated in Kazakhstan. Virus Genes. 2011;43:46-54.

14. Stallknecht DE, Senne DA, Zwank PJ, Shane SM, Kearney MT. Avian Paramyxoviruses from Migrating and Resident Ducks in Coastal Louisiana. J Wildl Dis. 1991;27:123-8.

15. Alexander DJ. Newcastle disease and other Paraymxoviridae infections. In: Calneck BW, Barnes HJ, Beard CW, Reid WM, Yoder H, editors. Diseases of Poultry. 1979.

16. LA Fornells MG, Silva TF, Bianchi I, Travassos CEPF, Liberal MHT, Andrade DM, et al. Detection of paramyxoviruses in Magellanic penquins (Spheniscus magellanicus) on the Brazilian tropical coast. Vet Microbiol. 2012;156:429-33.

17. Coffee LL, Hanson BA, Luttrell MP, Swayne DE, Senne DA, Goekiian VH, et al. Avian paramyxoviruses in shorebirds and gulls. J Wild Dis. 2010;46(2):481-7.

18. Ottis K, Bachmann PA. Isolation and characterization of ortho- and paramyxoviruses from feral birds in Europe. Zentralbl Vet Reihe B. 1983; 30:22-35

19. Nettles VF, Wood JM, Webster HG. Wildlife surveillance associated with an outbreak of lethal H5N2 avian influenza in domestic poultry. Avian Dis. 1985:29:733-41

20. Dundon WG, Heidari A, de Nardi R, Terregino C, Capua I, Cattoli G. Genetic variation of Italian avian paramyxoviruses serotype 9. Virus Genes. 2010: 41(1):43-46.

21. Miller PJ, Afonso CL, Spackman E, Scott MA, Pedersen JC, Senne DA, et al. Evidence for a new avian paramyxovirus serotype 10 detected in Rockhopper penguins from the Falkland Islands. J Virol. 2010;84(21):11496-504.

22. Briand FX, Henry A, Massin P, Jestin V. Complete genome sequence of a novel avian paramyxovirus. J Virol. 2012:86:7710.

23. Umali DV, Ito H, Katoh H, Ito T. Surveillance of Avian Paramyxovirus in Migratory Waterfowls in the San-in Region of Western Japan from 2006 to 2012. J Vet Med Sci. 2014;76(3):423-30.

24. Choi K-S, Kim J-Y, Kye S-J, Park C-K, Sung H-W. Genetic diversity of avian paramyxovirus type 4 isolates from wild ducks in Korea from 2006 to 2011 . Virus Genes. 2013;46:302-8.

25. Tian Z, Chai H, Li F, Sun J, Chen G, Hu X, et al. Complete Nucleotide Sequence of Avian Paramyxovirus Type 6 Strain JL Isolated from Mallard Ducks in China. J Virol. 2012:86(23):13112.

26. Yamane N, Arikawa J, Odagira T, Ishida N. Characterization of avian paramyxoviruses isolated from feral ducks in northern Japan: the presence of three distinct viruses in nature. Microbiol Immunol. 1982;26:557-68.

27. Shengqing Y, Kishida N, Ito H, Kida H, Otsuki K, Kawaoka Y, et al. Generation of velogenic Newcastle disease viruses from a nonpathogenic waterfowl isolate by passaging in chickens. Virology. 2002;301:206-11.

28. Coffee LL, Hanson BA, Luttrell MP, Swayne DE, Senne DA, Goekjian VH, et al. Avian paramyxoviruses in shorebirds and gulls. J Wildl Dis. 2010:46(2):481-7.

29. Fornells LAMG, Travassos CEPF, Costa CM, Novelli R, Petrucci MP, Soffiati FL, et al. Detection of Avian Paramyxoviruses in Migratory and Resident Birds in the State of Rio de Janeiro, Brazil. Avian Dis. 2013:57(4):780-4

30. Abolnik $C$, de Castro M, Rees J. Full genomic sequence of an African Avian Paramyxovirus Type 4 strain isolated from a wild duck. Virus Genes. 2012;45:537-41.

31. Goekiian VH, Smith JT, Howell DL, Senne DA, Swayne DE, Stallknecht DE. Avian Influenza Viruses and Avian Paramyxoviruses in Wintering and Breeding Waterfowl Populations in North Carolina, USA.J Wildl Dis, 2011:47(1):240-5.

32. Nayaka B, Nayaka S, Palduraia A, Kumara S, De Nardi R, Terregino C, et al. Evaluation of the genetic diversity of avian paramyxovirus type 4 . Virus Res. 2013:171:103-10. 
33. Xiaoa S, Subbiaha M, Kumara S, De Nardi R, Terregino C, Collins PL, et al. Complete genome sequences of avian paramyxovirus serotype 6 prototype strain Hong Kong and a recent novel strain from Italy: Evidence for the existence of subgroups within the serotype. Virus Res. 2010;150:61-72.

34. Cloud SS, Rosenberger JK. Characterization of nine avian paramyxoviruses. Avian Dis. 1980;24:139-52.

35. Yamane N, Arikawa J, Odagiri T, Ishida N. Characterization of avian paramyxoviruses isolated from feral ducks in northern Japan: the presence of three distinct viruses in nature. Microbiol Immunol.1982;26(7):557-68.

36. $\mathrm{WHO}$ - Identification of isolates by hemagglutination inhibition. In WHO - WHO animal manual: diagnosis and surveillance. Geneva: Department of Communicable Disease Surveillance and Response. WHO Global Programme, 2002. (WHO CDS/CSR/NCS/2002.5). 28 - 47.

37. Tong S, Shur-Wern Wang C, Li Y, Pallansch M, Anderson LJ. Sensitive and Broadly Reactive Reverse Transcription-PCR Assays To Detect Novel Paramyxoviruses. J Clin Microb. 2008;46(8):2652-8.

38. Tamura K, Peterson D, Peterson N, Stecher G, Nei M, Kumar S. MEGA5: Molecular Evolutionary Genetics Analysis using Maximum Likelihood, Evolutionary Distance, and Maximum Parsimony Methods. Mol Biol Evol. 2011;28:2731-9.

39. Tamura K, Nei M. Estimation of the number of nucleotide substitutions in the control region of mitochondrial DNA in humans and chimpanzees. Mol Biol Evol. 1993;10:512-26.

\section{Submit your next manuscript to BioMed Central and we will help you at every step:}

- We accept pre-submission inquiries

- Our selector tool helps you to find the most relevant journal

- We provide round the clock customer support

- Convenient online submission

- Thorough peer review

- Inclusion in PubMed and all major indexing services

- Maximum visibility for your research

Submit your manuscript at www.biomedcentral.com/submit 